\title{
The challenge of restoring tropical freshwater ecosystems
}

\author{
O desafio de restaurar ecossistemas aquáticos continentais tropicais
}

\author{
Reinaldo Luiz Bozelli ${ }^{1 *}$ (D)
}

${ }^{1}$ Laboratório de Limnologia, Departamento de Ecologia, Instituto de Biologia, Universidade Federal do Rio de Janeiro - UFRJ, Av. Carlos Chagas Filho, 373, Ilha do Fundão, CEP 21941-902, Rio de Janeiro, RJ, Brasil

*e-mail: bozelli@biologia.ufrj.br

Cite as: Bozelli, R.L. The challenge of restoring tropical freshwater ecosystems. Acta Limnologica Brasiliensia, 2019, vol. 31, e110.

Abstract : We are living a growing worldwide process of degrading the bases of sustaining life. In Brazil, this threat is intensified by the growing fragility of environmental protection structures. Ecological restoration is an alternative to face the degradation of aquatic environments. It has been employed on a larger scale in the developed regions of the planet, but with little convincing results. In Brazil, the experiences are few and specific, limited mainly by complexity and costs. It is necessary to think in a more agile way and act within the possibilities. The restoration with its classic strategies should give way to an "urgent restoration". This approach considers that we have the basic ecological information and professionals able to act in the resumption of control of the ecological processes that have been altered. Restoration in the condition of urgency implies beginning to think of protection, as a first step, turning attention to the management of the watershed. The way to regain control of the process where it was lost is the integrated management that involves the rational use and protection of the ecosystem. Brazil's commitment to the Paris climate agreement to restore 12 million hectares of forests and the restoration liabilities on private properties because of the recent Native Vegetation Protection Law are excellent opportunities to act in the integrated management of the river basin and to promote the protection of freshwaters by the restoration of native forests. The restoration of tropical freshwaters and especially the Brazilian ones is something urgent. However, possible solutions must be thought of and can only be constructed when one get involved most people related to the issue. The idea to be nurtured is that restoration involves thinking about the watershed because the threats are beyond the aquatic environment itself, the restoration then also needs to go beyond the aquatic environment itself.

Keywords: ecological restoration; freshwater; integrated management.

Resumo: Vivemos um processo mundial crescente de degradação das bases de sustentação da vida. No Brasil esta ameaça se intensifica pela fragilização crescente das estruturas de proteção ambiental. A restauração ecológica é uma alternativa para enfrentar a degradação dos ambientes aquáticos. Ela tem sido empregada em maior escala nas regióes desenvolvidas do planeta, porém com resultados pouco convincentes. No Brasil as experiências são poucas e específicas, limitadas principalmente pela complexidade e custos. É preciso então pensar de forma mais ágil e atuar dentro das possibilidades. A restauração com suas estratégias clássicas deve dar lugar a uma "restauração urgente". Esta abordagem considera que detemos as informaçôes ecológicas básicas e profissionais capazes para atuar na retomada do controle dos processos ecológicos que foram alterados. A restauração na condiçáo de urgência, implica pensar primeiro em proteção e voltar nossa atençáo ao manejo da bacia hidrográfica. A forma de recuperar o controle do processo onde ele foi perdido é o gerenciamento integrado que envolve o uso racional e a proteçáa do ecossistema. O compromisso do Brasil junto ao acordo do clima de 
Paris de restaurar 12 milhóes de hectares de florestas e os passivos de restauração em propriedades privadas, por causa do novo Código Florestal, são oportunidades de atuar no manejo integrado da bacia hidrográfica e promover a proteção das águas continentais pela restauração de florestas nativas. A restauração dos ambientes aquáticos continentais tropicais e especialmente dos brasileiros é algo urgente. No entanto, possíveis soluções têm que ser pensadas e só devem ser construídas envolvendo a maior parte das pessoas relacionadas com a questão. A ideia a ser nutrida é que a restauração envolve pensar na bacia hidrográfica, porque as ameaças estão além do ambiente aquático em si, e a restauração então, também precisa ir além do próprio ambiente aquático.

Palavras-chave: restauração ecológica; águas continentais; manejo integrado.

\section{Introduction}

When I read the convincing message of the United Nations (UN) warning that damage to the planet is so great that people's health will be increasingly threatened unless urgent action is taken, it seemed that I was re-entering the 1980s. This was a time when Brown (1985) noted that resource depletion and human alterations of natural systems were adversely affecting the economy, and he considered some of the facets of this relationship, such as population-induced climate change. Are we moving forward at all? Those years were democratically fragile with scarce protection of natural resources. These issues are on the table once again as we see politicians irresponsibly questioning the serious work of our environmental control institutions, pesticides banned worldwide being widely used, protected natural areas being reduced, and the whole system of environmental protection being weakened. We have made some progress, but not enough. The natural resources that sustain life are under increasing threat, and an unacceptable environmental setback has occurred. Environmental degradation and its consequences to life are occurring all over the world, affecting everyone, but they affect those who are poor much more.

\section{Ecological Restoration as an Alternative}

We have devoted time studying the preserved natural world, but almost no research has occurred on the altered world. Our knowledge must advance in this direction to minimize losses and to improve ecological integrity and human well-being (Cadotte et al., 2017). Among the strategies to achieve these goals, we can consider a local scale of remediation and restoration (Rohr et al., 2016). Ecological restoration as a strategy to reduce environmental damage is old and occurs in applied forms, such as erosion control and reforestation (Young et al., 2005). Recently, a strong academic field has attracted basic research and ample recognition. These scientific foundations and historical practices allowed it to gain space on the political agenda, becoming an object of global and regional initiatives of great importance. The Bonn Challenge is such a global effort to restore 150 million hectares of the world's deforested and degraded land by 2020 and 350 million hectares by 2030 . This goal is a practical means of realizing many international commitments, including the Aichi Target 15, the UN Framework Convention on Climate Change (UNFCCC) Reducing Emissions from Deforestation and Forest Degradation in Developing Countries (REDD+) goal, and the Rio+20 land degradation neutrality goal. Restoration is a significant part of the strategies listed in the UN's Sustainable Development Goals, especially in goals 14 (life below water) and 15 (life on land). More recently, the UN declared a decade for restoration (2021-2030). At a regional scale, we also see that restoration, at least as a concept and strategy, is nothing new, as it is already part of legal instruments for environmental management, such as Law 6938/81 (Brasil, 1981) and the Federal Constitution, in article 225 (Brasil, 1988). Following the worldwide trend of initiatives aimed at restoration, the Atlantic Forest Pact is a good example of this type of initiative. It aims to integrate efforts and resources to generate results for the restoration and conservation of biodiversity in 17 states of the Atlantic Forest biome. The Pact's goal is to implement the recovery of 15 million hectares by 2050 (PRMA, 2019).

\section{Technical Feasibility of Ecological Restoration}

Overcoming the idea of restoration, a detailed look at its technical feasibility will reveal a field of considerable complexity. The complexity, revealed by limnology, is intrinsic to rivers and lakes, marshes and pools in terms of their structure and function and is also related to the scales and time patterns in which they can be approached. Beyond this, complexity is amplified when we consider that the need for restoration arises mainly from innumerable problems in aquatic environments caused by human 
action. For example, these may be physical changes in watersheds and water bodies such as hydraulic modifications, chemical changes such as nutrient discharges of various origins or biological changes with the introduction of exotic species. In facing this growing complexity, the task of restoration must involve professionals other than the limnologists. Environmental engineers are needed to reduce inputs that degrade the systems, biologists are needed to manage species, hydrologists are needed to identify water flows that influence processes or interventions, management professionals are needed to manage the conditions for evolution and maintenance of interventions, and educators are need to raise awareness about the problem, its mitigation and the maintenance of the implemented solutions. Despite this complexity, great efforts have been made to restore degraded freshwater systems. Lakes are being neutralized, the input of nutrients is being reduced or trapped, fish assemblages are being manipulated, macrophytes are being withdrawn or biologically controlled, whole wetlands are being rebuilt, watercourses are being renaturalized, and margins are being revegetated. After twenty years, although still recently occurring (Sayer et al., 2019), ecological restoration remains a great challenge (Frid \& Clark, 1999) but has produced knowledge and methods and resulted in interventions. Some of these efforts have had good results, but others did not.

In eutrophic environments, the manipulation of biota has been attempted to improve water conditions. In general, this means has involved reducing algal biomass by reducing the abundance of zooplanktivorous fish, either by adding piscivorous fish or by manually removing undesired fish. Biomanipulation has been tested in several areas with variable results.

Acidification is another problem affecting some lakes as a result of our use of fossil fuels. One way to restore an acidified lake to its former $\mathrm{pH}$ is to add lime (calcium carbonate, CACO3). Liming is by far the most common in-lake technique for restoring acidified lakes, for example, in Scandinavian countries, the UK (Scotland and Wales) and eastern Canada.

Restoration is steadily becoming an essential part of national and international efforts to improve both water quality and the ecology of freshwater ecosystems, especially in Western Europe, the USA and Canada.

The two most common goals in the restoration of rivers and streams are the management of riparian areas and the improvement of habitats. To achieve these two objectives, it is necessary to develop a series of activities, such as replanting vegetation, excluding livestock from banks and maintaining riparian forest (Palmer et al., 2007). The restoration of lotic environments is a trend in the USA and Europe, although it is not uniform. Many river restoration centres throughout Europe are now promoting the importance of rivers and floodplains to support ecological diversity and sustainable options for flood management. Furthermore, the World Wildlife Fund project "Living Rivers for Europe" is working to protect and restore over 65 partnership projects within 25 European countries. However, a comprehensive evaluation study of 644 lotic restoration projects concluded that the results are disappointing (Palmer et al., 2014).

\section{Ecological Restoration of Tropical Aquatic Ecosystems (Some Studies, Few Experiences)}

Restoration remains a restricted activity in tropical freshwaters. Two main factors are central to this discussion: costs and knowledge. Costs are discussed below. Although restoration science and practice are spreading and are consistent in developed regions of the world, they are not simply and directly transferable. The principles of limnology are universal, but the situations to which they must be applied are different, and even if the problems are similar, the solutions should be different (Moss, 2005). Biomanipulation as a strategy for restoring freshwaters is an example. Significant differences in biotic interactions between temperate and subtropical and tropical environments make it very difficult to directly transfer and apply biological restoration strategies (Arcifa et al., 1995; Jeppesen et al., 2005). Numerous features of tropical ecosystems weaken the top-down links between piscivores and planktivorous fish and between zooplankton and phytoplankton (Lazzaro, 1997).

Restoration of aquatic environments in Brazil is as scarce as it is all tropical regions. Individually, the most investigated aspect has been the trophic relationships since they are the base of the biomanipulation. The results, especially for Brazilian reservoirs, suggest that there is a need for holistic approaches to obtain the necessary background information to design experiments, to interpret results and to use their findings for management (Arcifa \& Northcote, 1997). The best-known case is Paranoá Lake in Brasília, whose restoration project involved a reduction in the nutrient load (Cavalcanti et al., 1997) and biomanipulation 
(Starling et al., 1998). In the Pampulha Lagoon in Belo Horizonte, the strategy involved management of the watershed, construction of sedimentation basins, macrophyte removal and sediment removal (Von Sperling, 1997). Another example in Brazil is the Batata Lake in Pará, where the restoration process implemented nature-based solutions but also more traditional strategies, such as planting vegetation in flooded marginal areas of the lake (Bozelli et al., 2000; Scarano et al., 2018).

Another good restoration example of lotic environments is the Córrego Limpo Programme. Among the actions of this programme, the sources of secretly released sewage were controlled, and a collaborative governance action was implemented to raise awareness and educate the local population about maintaining clean streams. Until 2017, 151 streams were decontaminated, with investments of approximately R $\$ 254$ million (SABESP, 2019). However, the Programme still faces a great challenge because, despite the evident improvement in the environmental quality of the streams, they are still under the influence of diffuse loads (Silva $\&$ Porto, 2015). In Brazil, the experiences that most resemble the concept of river restoration as used in developed countries are programmes for the decontamination of river basins, for example, in the das Velhas River in Minas Gerais and the Tietê River in São Paulo (Meurer, 2010).

\section{Ecological Restoration Complexity and Costs}

Complexity is already evident in the diversity of terms and variables used between academics and practitioners to address restoration. As the topic area began to emerge, there was an increasing necessity to define its scientific identity. No one expressed this challenge better than Bradshaw (1987), who recognized that the practice of ecological restoration could be an "acid test" of ecological theory. Others have identified that the manipulative nature of ecological restoration is an ideal setting for hypothesis generation and testing in ecology (Jordan et al., 1987). In the first years of its development,

[...] restoration science gained a strong academic foothold, recognized problems faced by practitioners, brought new focus to existing ecological theory and fostered a handful of novel ecological ideas [...] (Young et al., 2005, p. 662).

Failure to correctly address certain problems demonstrated the need to base restoration on the best ecological knowledge possible. However, in this paper, we are referencing tropical environments where complexity far exceeds that of temperate environments and where the production of science has a recent history and slower growth. This scenario helps to understand why there are few examples of restoration of aquatic ecosystems in Brazil, especially if we consider direct interventions (active restoration) by humans.

If all the scientific knowledge required for a project is available, which is rarely the case, then it is not possible to move forward without considering the available funds and projected costs because high costs limit restoration activities. The success of a restoration project depends on economic efficiency and adequate capital (Bernhardt \& Palmer, 2011). Costs are high and prohibitive when considering the dominant political and economic views in Brazil. It is a moment of changes in politics, in the vision that drives private enterprises and in the legal framework for the environment. Generally, limited resources should be scarcer in times of crisis, reforms and progressive displacement of the environmental basis and its role in all human activity.

Ecological restoration needs autochthonous science because successful restoration requires grounding and guidance from the knowledge of the structure and functioning of a given ecosystem and the extent of damage to these systems. Restoration still requires technical and practical knowledge that does not necessarily have to be autochthonous, but if not, then it reinforces our financial dependence and keeps restoration costs prohibitive. Even countries with significant technical and scientific knowledge, as well as resources to invest, have not achieved the expected results. After reviewing a wide variety of stream restoration projects (345 studies), few strong conclusions could be reached

[...] because of the limited information provided on physical habitat, water quality, and biota and because of the short duration and limited scope of most published evaluations [...] (Roni et al., 2008, p. 856).

The short duration and limited scope of most published evaluations are related to limited funds.

\section{Classical Restoration can "wait", but Science Will Continue to Produce Knowledge}

For this article, the ecological restoration of aquatic environments are considered classical aquatic restoration. Classical restoration means direct interventions in the altered ecosystems to promote the desired changes and restore the environment to a 
recovered state (McDonald et al., 2016). Therefore, the interventions can be physical or chemical processes such as aeration, dredging, liming, renaturalization of riverbeds, or biological processes such as biomanipulation and biological control of macrophytes. This restoration still presupposes having a reference ecosystem, an intervention that is not unique, an articulated nature, with objectives and goals aimed at recovering the structure and functions of a given ecosystem, and recognized reach and social involvement.

Classical ecological restoration can wait, and it will have to wait, given the objective conditions it presupposes. This does not mean that in a very specific and localized way, it cannot be employed. Lake Batata is one such case. Very altered aquatic environments in urban centres or even some aquatic environments have localized pollution due to an accident or even negligence. In some situations, the law may also require restoration. Classic restoration must wait because the chances of success are reduced when fundamental conditions such as sound ecological knowledge and financial resources do not exist. Although the availability of resources may be something more distant, science, even threatened, will continue its course producing ecological knowledge and indigenous technical solutions that can reduce the number of monetary resources needed. However, if the conditions for classic restoration are limited, then the threats to aquatic ecosystems continue.

We must put aside the romantic feeling that we can fix the environment as if repairing any equipment. This attitude considers the urgency of the moment and points to greater pragmatism and simplicity in action. Classical restoration must momentarily give way to "urgent restoration" that could also be considered "desperate restoration". For the ecological restoration of freshwater ecosystems, the path is shorter since we already have most of the knowledge and many necessary tools, especially those of the social realm. The financial resources would be smaller than those needed in a classical strategy because of the low technical complexity of the interventions and connections with other initiatives already underway.

\section{7. “Urgent restoration” or Retaking Control of the Processes}

In general, there are no minimum conditions in Brazil for classic restoration to be applied at an appropriate scale, and before the degradation of aquatic environments reaches levels where it is no longer possible to return, one must act through "urgent restoration". An initial clarification concerns the use of the term in quotation marks. This decision suggests that "urgent restoration", depending on the understanding of the activity, is only part of the process, usually focused on eliminating the causes of degradation. On the other hand, depending on the scope and the monitoring planned and executed for it, there is no doubt that the restoration would be a complete action. In practice, we observe a continuum with several possible situations that are predominantly, for reasons already explained, situations in which interventions are only possible initially or for a short duration. The urgency or resumption of process control recognizes that we have sufficiently developed ecological science to identify, qualify and quantify, at a relatively early stage, most of the problems related to degradation of aquatic environments. Our research groups and limnologists are scattered throughout Brazil and rely on the minimal technology and expertise necessary for restoration. When the process takes place in this way, there is a reduction in costs and an increase in the chances of success.

The main problems of continental aquatic environments in Brazil are the organic pollution that leads to eutrophication and the high loads of inorganic material that lead to water turbidity and environmental silting. We still consider the problem of damming rivers that changes their dynamics and finally the withdrawal of water for different purposes that can compromise the environment. In all these situations, the best way to approach them is prevention, avoiding the exacerbation of the problem with the complete loss of control of the process. Resuming the process in the first category of problems means regaining control of nutrients, such as those that are directly released in aquatic environments or that arrive there from the landscape when used, for example, in agriculture. The problem of turbidity and silting of aquatic environments means a progressive loss of sediment by soil erosion. Resuming control means prioritizing soil care to avoid net soil losses. In cases where the problem means its direct use, water must be available at a sufficient quantity, quality or both. In this case, regaining control of the process means paying attention to the water cycle that, in normal conditions, provides sufficient quantity and quality as long as the landscape has preserved its structure and function. 


\section{Before Needing to Restore, we Have Long Had to Manage in an Integrated Way}

We have several examples of freshwater environments worldwide that have been subjected to severe environmental degradation. In Brazil, we also have some examples, but fortunately, we can say with absolute certainty that it is still a small number of environments. However, this does not negate the urgency of the situation. Because acting in advance has an advantage. Acting responsibly means managing because it is better and easier to learn to use than trying to fix something. In all circumstances of damage to previously harmed environments, the way to regain control of the process where it was lost is integrated management that involves the rational use and protection of the ecosystem. Stating the need for integrated management means that a sewage treatment plant is not enough to solve the problem of organic pollution. However, if it is accompanied by monitoring, education and shared decision-making, the plant will be more likely be able to guarantee the quality of a specific environment. Water management in Brazil is guided by holistic principles and recognizes the river basin as a management unit. When considering the watershed, the aquatic environment will be seen in an integrated way, and it is easier to recognize which processes need to be controlled.

There is something wrong in the way we view these relationships, as the possibility of restoring aquatic environments, which is still very questionable, should not dull the thought and possibility of protecting these environments. Restoration in the condition of urgency implies to start thinking about protection as a first step. The example of Mariana (MG) seems appropriate. Much was lost with the disaster, but what did the watersheds have to resist degradation? What remains in the watershed as a starting point for restoration that can be sought? Being able to restore does not mean that it should not be protected. Protecting ecosystems may be the initial input needed for restoration to follow, and the input should be passive. For example, is it possible to think of dredging $600 \mathrm{~km}$ of river and other $\mathrm{km}^{2}$ of the sea as in the case of Mariana? This landscape, in this case, although locally other strategies may be used, must have maintained and expanded its capacity to produce water to flood the landscape, disperse the propagules and dilute the problem.

Turning attention to river basin management as a priority action before restoration also means increasing conservation priorities, betting that natural systems are more efficient to withstand the imposed changes and contributing more at the moment when some level of restoration is needed. The global situation of projects aimed at the restoration of lotic environments suggests that efforts at the watershed and riparian scales restoring hydrological processes and preventing of pollutants from streams appear to offer the most promise (Palmer et al., 2014). More promising seems to be the scenario of the ecological restoration of forested environments. Here, the importance of the strategy of urgent restoration reappears when prioritizing preventive action in the watershed. The Brazilian commitment to the Paris Climate Agreement provides for the restoration of 12 million hectares of forest by 2030 and 21 million hectares to be restored or compensated for through the maintenance of native forests.

Protecting and restoring forests where we walk and want to have in the watershed as relatively intact ecosystems are key to biodiversity conservation and help in the recovery of degraded ecosystems. Thus, restoration becomes a complementary activity that when combined with protection, can help achieve more comprehensive outcomes across a watershed. Even for specific water bodies where restoration needs to be implanted, the first objective should be the prevention of future degradation. Monitoring water quality and restoration of in-lake processes alone will be futile if not carried out in a watershed context. This latter involves documenting the entire landscape setting, including habitat type, hydrological regime, soil properties, topography, and invasive species, all of which can hamper restoration measures (Gulati \& Van Donk, 2006). Thus, ecosystems are open and connected, especially aquatic ones, which by the intrinsic characteristics of the water that floods the whole landscape, and ecosystems cannot be considered in isolation but need to be treated as part of a whole, need to be managed in an integrated way.

An example of initiatives that help us think about the restoration of Brazilian aquatic environments in a way is more adjusted to our developing country's environmental reality is the question of the revitalization of the São Francisco River. The concept of river basin revitalization is still under development in Brazil, but a tentative definition can be outlined as follows:

A series of actions planned within a river basin, with the aim of adapting the management of water resources physical, biotic, demographic, economic, social and cultural diversities of the 
basin through the pollution removal from sewage and agrochemical water, soil conservation, coexistence with climate diversity, reforestation of riparian forests, integrated management of solid waste, environmental education and the creation and management of conservation units (Machado, 2008, p. 197).

\section{Final Remark}

The restoration of tropical freshwaters, especially Brazilian freshwaters, is urgent. However, possible solutions are to be identified and constructed by us, although the foundations of science for this are universal. We need to have the courage and the audacity to let go of classic restoration and recognize the urgency of "urgent restoration". The idea to consider is that restoration involves thinking of the watershed because the threats are beyond the aquatic environment itself; thus, restoration also needs to go beyond the aquatic environment. After all, it is necessary to reconcile the essence of the environment, to know it, to accept it in its particularities and to enhance its characteristics.

\section{References}

ARCIFA, M.S. and NORTHCOTE, T.G. Need for holistic approaches in food web experiments and biomanipulation in tropical lakes: a Brazilian reservoir experience. Verh. Internat Verein Limnol., 1997, 26(2), 661-665. http://dx.doi.org/10.1080/0 3680770.1995 .11900798$.

ARCIFA, M.S., STARLING, F.L.R., SIPAÚBATAVARES, L.H. and LAZARRO, X. Experimental limnology In: J.G. Tundisi, C.E.M. Bicudo and T. Matsumura-Tundisi, eds. Limnology in Brazil. Rio de Janeiro: Academia Brasileira de Ciências, 1995, pp. 257-281.

BERNHARDT, E.S. and PALMER, M.A. River restoration: the fuzzy logic of repairing reaches to reverse catchment scale degradation. Ecological Applications, 2011, 21(6), 1926-1931. http://dx.doi. org/10.1890/10-1574.1. PMid:21939034.

BOZELLI, R.L., ESTEVES, F.A. and ROLAND, F., eds. Lago Batata: impacto e recuperação de um lago amazônico. Rio de Janeiro: SBL/IB, 2000.

BRADSHAW, A.D. Restoration: the acid test for ecology. In: W.R. JORDAN, M.E. GILPIN and J.D. ABER. Restoration ecology: a synthetic approach to ecological research. Cambridge: Cambridge University Press, pp. 23-29, 1987.

BRASIL. Constituição da República Federativa do Brasil de 1988 [online]. Brasília, DF, 1988 [viewed 12 Apr. 2019]. Available from: http://www.planalto.gov.br/ ccivil_03/Constituicao/Constituicao.htm
BRASIL. Lei no 6.938, de 31 de agosto de 1981. Dispóe sobre a Política Nacional do Meio Ambiente, seus fins e mecanismos de formulação e aplicação, e dá outras providências. Diário Oficial da União [da] República Federativa do Brasil [online], Poder Executivo, Brasília, DF, 1981 [viewed 12 Apr. 2019]. Available from: http://www.planalto.gov.br/Ccivil_03/Leis/ L6938.htm

BROWN, L. A false sense of security. In: L. Brown, E.C. Wolf, L. Starke, W.U. Chandler, C. Flavin, S. Postel and C. Pollack, eds. New York: W. W. Norton, 1985, pp. 3-22.

CADOTTE, M.W., BARLOW, J., NUÑEZ, M.A., PETTORELLI, N. and STEPHENS, P.A. Solving environmental problems in the Anthropocene: the need to bring novel theoretical advances into the applied ecology fold. Journal of Applied Ecology, 2017, 54(1), 1-6. http://dx.doi.org/10.1111/13652664.12855 .

CAVALCANTI, C.G.B., PINTO, M.T., FREITAS, H.J. and MOREIRA, R.C.A. Paranoá Lake restoration: impact of tertiary treatment of sewage in the watershed. Verhandlungen des Internationalen Verein Limnologie, 1997, 26(2), 689-693. http://dx.doi.or g/10.1080/03680770.1995.11900803.

COMPANHIA DE SANEAMENTO BÁSICO DO ESTADO DE SÃO PAULO - SABESP. Programa Córrego Limpo [online]. São Paulo: SABESP, 2019 [viewed 12 Apr. 2019]. Available from: http://site.sabesp.com.br/site/interna/Default. aspx?secaoId $=116$

FRID, C.L.J. and CLARK, S. Restoring aquatic ecosystems: an overview. Aquatic Conservation: Marine and Freshwater Ecosystems, 1999, 9(1), 1-4. http://dx.doi.org/10.1002/ (SICI) 1099-0755(199901/02)9:1<1::AIDAQC321>3.0.CO;2-3.

GULATI, R.V. and VAN DONK, E. Restoration of freshwater lakes. In: J. Andel \& J. Aronson, eds. Restoration ecology the new frontier. USA: Blackwell Publishing, 2006, pp. 158-173.

JEPPESEN, E., SØNDERGAARD, M. MAZZEO, N., MEERHOFF, M., BRANCO, C.W.C, HUSZAR, V. and SCASSO, F. Lake restoration and biomanipulation in temperate lakes: relevance for subtropical and tropical lakes. In: M.V. Reddy, ed. Tropical eutrophic lakes. Enfield: Science Publisher Inc., 2005, pp. 341-360.

JORDAN, W.R., GILPIN, M.E. and ABER, J.D. Restoration ecology: ecological restoration as a technique for basic research. In: W.R. Jordan, M.E. Gilpin and J.D. Aber, eds. Restoration ecology: a synthetic approach to ecological research. Cambridge: Cambridge University Press, 1987, pp. 3-22.

LAZZARO, X. Do the trophic cascade hypothesis and classical biomanipulation approaches apply to tropical lakes and reservoirs. Verhandlungen des 
Internationalen Verein Limnologie, 1997, 26, 719 730. http://dx.doi.org/10.1080/03680770.1995.1 1900811 .

MACHADO, A.T.M. A construçáo de um programa de revitalizaçáo na bacia do Rio São Francisco. Estudos Avançados, 2008, 22(63), 195-210. http://dx.doi. org/10.1590/S0103-40142008000200013.

MCDONALD, T., GANN, G.D., JONSON, J. and DIXON, K.W. International standards for the practice of ecological restoration - including principles and key concepts. Washington: Society for Ecological Restoration, 2016, 48 p.

MEURER, M. A restauração fluvial e a busca de reconciliação da Europa com seus corpos d'água: $\mathrm{O}$ que o Brasil deve aprender com esta experiência? Geographica (Madrid, Spain), 2010, 12(23), 124-139.

MOSS, B. 2005. Forward-I. In: M.V. Reddy, ed. Tropical eutrophic lakes. Enfield: Science Publisher Inc. 2005, p. iv-vii.

PACTO PARA A RESTAURAÇÃO DA MATA ATLÂNTICA - PRMA. Objetivo e meta [online]. Recife: PRMA, 2019 [viewed 12 Apr. 2019]. Available from: https://www.pactomataatlantica. org.br

PALMER, M.A., ALLAN, J.D., MEYER, J. and BERNHARDT, E.S. River restoration in the twentyfirst century: data and experiential knowledge to inform future efforts. Restoration Ecology, 2007, 15(3), 472-481. http://dx.doi.org/10.1111/j.1526100X.2007.00243.x.

PALMER, M.A., FILOSO, S. and FANELLI, R.M. From ecosystems to ecosystem services: stream restoration as ecological engineering. Ecological Engineering, 2014, 65, 62-70. http://dx.doi. org/10.1016/j.ecoleng.2013.07.059.

ROHR, J.R., FARAG, A.M., CADOTTE, M.W., CLEMENTS, W.H., SMITH, J.R., ULRICH, C.P. and WOODS, R. Transforming ecosystems: when, where, and how to restore contaminated sites. Integrated Environmental Assessment and Management, 2016, 12(2), 273-283. http://dx.doi.org/10.1002/ ieam.1668. PMid:26033665.

RONI, P., HANSON, K. and BEECHIE, T. Global review of the physical and biological effectiveness of stream habitat rehabilitation techniques. North American Journal of Fisheries Management, 2008, 28(3), 856-890. http://dx.doi.org/10.1577/M06169.1 .

SAYER, C.H., BENNION, A., GURNELL, E., GOODYER, D., KOTZE, A. and LINSAY, R. Restoration of freshwaters: principles and practice. In: J.M.R. Hughes, ed. Freshwater ecology and conservation approaches and techniques. Oxford: Oxford University Press, 2019, pp. 378-398.

SCARANO, F.R., BOZELLI, R.L, DIAS, A.T.C., ASSIREU, A., CAPOSSOLI, D.J., ESTEVES, F.A., FIGUEIREDO-BARROS, M.P., NUNES, M.F.Q.S., ROLAND, F., SANSEVERO, J.B.B., RAJÃO, P.H.M., REIS, A. and ZAMITH, L.R. Twenty-five years of restoration of an Igapó Forest in Central Amazonia, Brazil. In: R.W. Myster, ed. Igapó (Black-Water Flooded Forests) of the Amazon Basin. USA: Springer, 2018, pp. 279-294. http://dx.doi. org/10.1007/978-3-319-90122-0_15.

SILVA, J.C.A. and PORTO, M.F.A. Recuperação de córregos urbanos através do controle de cargas pontuais e Difusas. Córrego Ibiraporá, SP. Revista Brasileira de Recursos Hidricos, 2015, 20(1), 82-90. http://dx.doi.org/10.21168/rbrh.v20n1.p82-90.

STARLING, F.L.R., BEVERIDGE, M., LAZZARO, X. and BAIRD, D. Silver carp biomass effects on plankton community in Paranoá Reservoir (Brazil) and an assessment of tis potential for improving water quality in lacustrine environments. International Review of Hydrobiology, 1998, 83, 499-508.

VON SPERLING, E. Methodological aspects by the selection of restoration strategies of tropical urban lakes. Internationale Vereinigung für Theoretische und Angewandte Limnologie: Verhandlungen, 1997, 26(2), 786-788. http://dx.doi.org/10.1080/03680770.199 5.11900824 .

YOUNG, T.P., PETERSEN, D.A. and CLARY, J.J. The ecology of restoration: historical links, emerging issues and unexplored realms. Ecology Letters, 2005, 8(6), 662-673. http://dx.doi.org/10.1111/j.14610248.2005.00764.x.

Received: 17 April 2019 Accepted: 18 October 2019 